Moon", D. Caradog Jones on "The Changing Population of Merseyside", Prof. J. T. Craig on "Veterinary Pathology", and a number of shorter talks were given in the individual rooms. The Institute of Chemistry and the Society of Chemical Industry exhibited process demonstrations of artificial silk spinning, products obtainable from cotton seed, demonstrations of the action of dirt particles under the influence of electrical forces, dyeing and armourplate glass; the British Association of Chemists exhibited a combined temperature and humidity recorder, smoke density determination apparatus and samples from the plastics industry. The Liverpool Biological Society's room included a demonstration exhibit by Prof. J. H. Orton on his Dee fisheries work, Dr. R. J. Daniel on pearl-formation, and Mrs. Bisbee on the ductless glands. Mr. Eric Hardy had arranged a special "Country-Side" Room with Nature films, photographs, habitat groups of British birds and mammals, bird migration ('ringing') and flight (bird-wing) displays, illuminated natural colour lantern slides, bird sanctuary devices and maps of local bird distribution. The exhibition also included natural colour films, an ingenious microprojector by Mr. A. V. Wilkinson, Dr. Glynn Morris's geological collection, and in the Engineering Society's room, a trafficator for cyclists invented by $\mathrm{Mr}$. A. Robins.

\section{Indian Adult Education}

From the National Adult School Union we have received a copy of an appeal by its International Committee for funds to assist in the development of adult education work in India. The appeal is countersigned by Mr. Banning Richardson, as president of the Indian Adult Education Society and honorary general secretary, All-India Adult Education Conference Committee. This committee has undertaken to investigate all the adult education activities which are being carried on in India and to call a conference for the early part of 1939. Annexed to the appeal is a leaflet which mentions, as indicative of the character of the work now carried on by the Indian Adult Education Society: the teaching of improved methods of handicrafts to undergraduates of the University of Delhi with the intention that during the vacations this instruction should be passed on to their rural relations and friends; "literacy work" ; a regular service of rural broadcasting; the teaching of scholastic subjects to matriculates, who have not been able to continue their studies at a university ; and the giving of instruction to members in their own religion by the most capable believer in that faith available. Of this last, it is claimed that an improved relationship between the followers of the different religions has resulted. Nothing is said about the utilization of the movement as an instrument of political propaganda, but reference is made to the fact that in the Central Provinces, recently described in The Hindu as "a thoroughly congressminded province", the Minister of Education and Vice-Chancellor of the University have associated themselves with it.

\section{Royal Society of Science, Bombay}

SrNCE its opening in 1920, the Royal Institute of Science, Bombay, has been recognized as the foremost college in the Presidency for the training of science students. The late Dr. A. N. Meldrum, the first principal and professor of organic chemistry, realized the importance of its being not merely an institution for the training of undergraduate students, but that it should also be an active centre of research. He was fortunate in having the support of an enthusiastic staff, and during the period of his principalship a large number of students were trained in the methods of research both in the physical and natural sciences. We have now before us the triennial report of the Institute covering the years 1934-37, and we note with pleasure the continued advancement of the Institute under the energetic and enlightened leadership of its present principal, Prof. T. S. Wheeler. The total number (315) of full-time students is not large, and of these no fewer than 94 are engaged in post-graduate work, which indicates the importance attached to original work.

DURING the triennium dealt with in the report, 159 original papers have been published of which the majority (102) come from the two departments of chemistry. Whilst, as is natural, their contents are of varying value, Prof. T. S. Wheeler's contributions to the theory of liquids and Prof. R. H. Dastur's work on plant metabolism have attracted widespread attention. In its recent visit to Bombay, the British science delegation had the opportunity, all too short, of visiting the Institute and of seeing something of the work which is being so actively pursued. Contrary to the experience elsewhere in India, no difficulty has been encountered in finding employment for students, of whom only 0.6 per cent were unemployed, whilst 21.8 per cent had obtained industrial posts. It is very much to be hoped that no considerations of economy will be allowed to weaken the activities of the Institute since, to the students now under training there, the industries of the Bombay Presidency must largely look for their future advancement.

\section{Acquisitions at the British Museum (Natural History)}

THRovar the kindness of the Rev. T. H. Wilson, of Inkongo in the Sankuru district of the Congo, the Museum has received a female specimen of the recently discovered peacock-like bird, Afropavo congensis. This bird was first discovered by Dr. James P. Chapin, of the American Museum of Natural History, New York, in 1936, who found two mounted examples in the Ethnological Department of the Tervueren Museum, Brussels, where they had been overlooked. Later the authorities of that Museum received further specimens from the Congo. Dr. Chapin visited the area and his native hunters brought in two more, while he himself had a fleeting view of one bird in the forest. The interesting feature of this bird is that in some of its characters it resembles the peacock, a bird which is confined to Asia. Specimens of diamondiferous gravels and concentrates have been 